\title{
Evaluation of Physicochemical and Functional Properties of Protein Recovered Obtaining from Whitemouth Croaker (Micropogonias furnieri) Byproducts
}

\author{
Fabiano de Andrade Ferreira ${ }^{1 *}$, Bruno Pereira Freire ${ }^{1}$, Juliana Taís Andreghetto de Souza, \\ William Renzo Cortez-Vega ${ }^{2}$, Carlos Prentice ${ }^{1}$ \\ ${ }^{1}$ Laboratory of Food Technology, Department of Chemistry, Federal University of Rio Grande, Rio Grande, Brazil; ${ }^{2}$ Laboratory of \\ Bioengineering, Faculty of Engineering, Federal University of Grande Dourados, Dourados, Brazil. \\ Email: engfabianof@zipmail.com.br
}

Received February $27^{\text {th }}, 2013$; revised March $27^{\text {th }}, 2013$; accepted April $4^{\text {th }}, 2013$

Copyright (C) 2013 Fabiano de Andrade Ferreira et al. This is an open access article distributed under the Creative Commons Attribution License, which permits unrestricted use, distribution, and reproduction in any medium, provided the original work is properly cited.

\begin{abstract}
Proteins recovered were obtained from Whitemouth Croaker (Micropogonias furnieri) byproducts and their physicochemical and functional properties were evaluated. The proximate composition, presented $8.64 \% \pm 0.10 \%$ of moisture, $85.33 \% \pm 0.12 \%$ of protein, $2.69 \% \pm 0.09 \%$ of ashes and $2.16 \% \pm 0.12 \%$ of lipids, in dry basis. The highest solubility was obtained in $\mathrm{pH} 11$ (93.24\%), the maximum water holding capacity was presented at pH $11\left(25.71 \mathrm{~mL} \mathrm{H} \mathrm{H}_{2} \mathrm{O} / \mathrm{gpro}-\right.$ tein), the oil holding capacity was $13.71 \mathrm{~mL} /$ gprotein and the digestibility in vitro was $91.32 \% \pm 0.15 \%$. The electrophoretic profile was observed typical of the myofibrillar proteins, with the appearance of the heavy chain of myosin $(220 \mathrm{kDa})$ and actin $(50 \mathrm{kDa})$. The results show that the products of low commercial value of fish that are usually used for the production of animal feed or simply discarded, contributing to environmental pollution, may be used to produce products with a greater added value.
\end{abstract}

Keywords: Whitemouth Croacker; Protein; Byproducts; Properties

\section{Introduction}

The Whitemouth Croacker (Micropogonias furnieri) is a migratory euryhaline teleostean demersal fish found in the Atlantic Ocean from Northern Venezuela $\left(20^{\circ} \mathrm{N}\right)$ to the Gulf of St. Mathias $\left(41^{\circ} \mathrm{S}\right)$, Argentina. Over $50 \%$ of the total fisheries production in the region (south of Brazil) is supported by sciaenid species and the Whitemouth Croacker is one of the most abundant and important for local fisheries [1].

In fish, the filet is the item of economic value, and yield varies according to fish size and the technological field of processing companies. Therefore their yield may reach $30 \%$ to $40 \%$ by weight of the animal with the remainder being considered as waste and of no commercial value (leftover meat, head, skin, bones, scales and guts). Thus, alternative sources of protein such as the byproducts of fish become important since they constitute $60 \%$ $70 \%$ of raw material and are discarded by filleting Indus-

*Corresponding author. tries causing environmental damage [2].

The term residue refers to waste and byproducts of food processing that are relatively low in value [3]. It features the head, skin, scales, bones and viscera [4], which depend on species may reach $66 \%$ of the total weight [5]. The restructured food products developed from the byproducts not only allow the seafood industry to diversify its product offerings, but also provide another source of protein of high nutritive value to meet human nutritional needs and reduce environmental problems associated with seafood processing [6-8].

The knowledge of specific functional properties of protein isolates facilitates their adequate implementation, contributing to better technology use. A good solubility of proteins is necessary for many applications, especially for emulsions, foams and gels [9]. The oil holding capacity is of great importance in the formulation of food, being able to influence the order of addition of dry ingredients into the mixture, besides being used to determine the mixing times using a uniform distribution of oil or fat 
in the dry mixtures [10].

The aim of this study was to evaluate of physicochemical and functional properties of protein recovered obtaining from Whitemouth Croaker (Micropogonias furnieri) byproducts (PRWC).

\section{Materials and Methods}

\subsection{Obtaining the Protein Recovered}

The raw material, the fresh croakers (Micropogonias furnieri), were obtained from fish processing plants of the city of Rio Grande, Southern Brazil and transported under refrigerated conditions to the Laboratory of Food Technology, of Federal University of Rio Grande, FURG.

Mechanically deboned croaker meat was prepared which was eviscerated, filleted and soon after that passed through a meat bone separator (Baader model 694, Lübeck, Germany). The protein recovered obtained were washed in three cycles utilizing in each cycle a washing solution:meat ratio of $4: 1(\mathrm{v} / \mathrm{w})$, temperature of $7^{\circ} \mathrm{C}$, for $10 \mathrm{~min}$. In each washing cycle, the stirring was kept constant at $220 \mathrm{rpm}$ using a mechanical agitator (Marconi model MA-259, Piracicaba, Brazil). A $0.5 \% \mathrm{NaHCO}_{3}$ solution was utilized for the first and second washings and $0.3 \% \mathrm{NaCl}$ solution was used for the last one. After each washing cycle, the samples were centrifuged at $7^{\circ} \mathrm{C}$ (Sigma model 6-15, Osterode, Germany). The first and second centrifugations were carried out at $3000 \times \mathrm{g}$ for 15 min, while the third one at $7000 \times \mathrm{g}$ for $25 \mathrm{~min}$. The supernatant containing fat and water-soluble proteins was discarded. The final slurry was sieved through a $1-\mathrm{mm}$ mesh metal screen to remove connective tissues [11].

\subsection{Proximate Composition}

The moisture contents, proteins, lipids and ash, were determined in triplicate according to the method described by AOAC [12].

\subsection{Functional Properties}

\subsubsection{Protein Solubility}

It was determined according to the method of Chalamaiah [13] and Tadpitchayangkoon [14] adapted to laboratory conditions, with varying $\mathrm{pH}(3,5,7,9$ and 11). In general, $0.5 \mathrm{~g}$ of the sample was weighed into a beaker of $50 \mathrm{~mL}$ and $2 \mathrm{~mL}$ of $0.1 \mathrm{M} \mathrm{NaCl}$ and $48 \mathrm{~mL}$ of distilled water was added. The $\mathrm{pH}$ was adjusted with $\mathrm{HCl} 1 \mathrm{~N}$ and $\mathrm{NaOH} 1 \mathrm{~N}$. The dispersion was kept under stirring for 30 minutes on a magnetic stirrer (QUIMIS, model 261-2), then centrifuged for 20 minutes at $8667 \times \mathrm{g}$ in a tubes centrifuge (Biosystems, Model: MPW-350R). The soluble protein content in the supernatant was determined by the Folin-Ciocalteau method according to Lowry [15]. The solubility of protein was calculated according to the Equation (1). For the calculation of protein in the supernatant albumin the standard curve was used.

$$
\% \mathrm{~S}=\frac{\text { Protein content in supematant }}{\text { Total protein content in sample }} \times 100
$$

\subsubsection{Determination of Water Holding Capacity (WHC)}

The WHC was determined according to the method of Regenstein [16] adapted to the laboratory conditions. Protein dispersion was prepared at $1 \%$ with $\mathrm{pH}$ variation of (3, 5, 7, 9 and 11). $2 \mathrm{~mL}$ of $\mathrm{NaCl} 0.1 \mathrm{M}$ was added to the dispersion to obtain a smooth paste, and then the corresponding buffer solution was added according to the corresponding $\mathrm{pH}$ up to the volume of $40 \mathrm{~mL}$, the dispersion was kept under stirring for 15 minutes and centrifuged at $8667 \times \mathrm{g}$ for 20 minutes. The soluble proteins in the supernatant were quantified by the method of Bradford [17], and deducted from the total protein of the original sample. The WHC was determined by Equation (2).

$$
\mathrm{WHC}=\frac{\text { Amount of water retained }(\mathrm{mL})}{\text { Original mass of protein }(\mathrm{g})}
$$

\subsubsection{Determination of the Oil Holding Capacity (OHC)}

The OHC was determined according to the method described by Fonkwe and Singh [18], $0.5 \mathrm{~g}$ of protein was weighed and mixed with $10 \mathrm{~mL}$ of soybean oil in centrifuge tubes and shaken for $10 \mathrm{~min}$ in a tube agitator at speed 4 (PROENIX AP 56). Later, the mixture was centrifuged at $8667 \times \mathrm{g}$ for 20 minutes, and the difference between the added oil and the unretained oil was considered as the amount of oil retained by the isolates. The result was obtained using the Equation (3).

$$
\mathrm{OHC}=\frac{\text { Oil retained }(\mathrm{mL})}{\text { Protein mass }(\mathrm{g})}
$$

\subsubsection{Digestibility in Vitro}

The determination of protein digestibility in vitro was performed by enzymatic digestion with pepsin (specific activity of $10^{7} \mu \mathrm{g}$ tyrosine $/ \mathrm{min} / \mathrm{mg}$ prot) in $0.1 \mathrm{~N} \mathrm{HCl}$ and pancreatin (specific activity of $24 \mu \mathrm{g}$ tyrosine $/ \mathrm{min} / \mathrm{mg}$

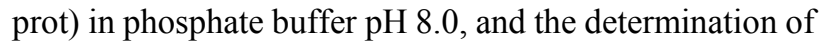
amino acid released accomplished by the method of Lowry [15]. Concentrations were calculated based on standard curve of tyrosine, whose concentration ranged between 3 and $11 \mu \mathrm{g} \cdot \mathrm{mL}^{-1}$ [19].

\subsection{Electrophoresis of Protein Recovered}

SDS-PAGE (sodium dodecyl sulfate) was performed according to the method of Laemmli [20]. The charac- 
terization of the protein recovered fractions was performed by polyacrylamide gel electrophoresis in presence of sodium dodecyl sulfate. The electrophoretic analysis was performed on a vertical electrophoresis unit (GSR/ 300STS). SDS-PAGE separation was performed in a continuous buffer system consisting of $1.5 \mathrm{M}$ Tris buffer and $10 \%$ SDS (w/v). The gel was prepared with a $12 \%$ separating gel and a $4 \%$ gel concentration. The samples were dissolved in $1.5 \mathrm{~mL}$ distilled water to form a solution containing $0.2 \%$ protein. Samples were thermally denatured at $95^{\circ} \mathrm{C}$ for $4 \mathrm{~min}$ in a solution of b-mercaptoethanol, $0.5 \mathrm{M}$ Tris (pH 6.8), glycerol, $10 \%$ SDS (w/v) and $0.1 \%$ bromophenol blue $(\mathrm{w} / \mathrm{v})$. To identify the proteins present in the samples, Bio-Rad marker ladders were used. Bands were revealed with Coomassie Brilliant Blue R-250 (Vetec Química Fina LTDA, Rio de Janeiro, Brazil).

The determination of protein fractions was performed by molecular weight. A mixture of standard proteins (BenchMark $^{\mathrm{TM}}$ Protein Ladder, California, USA), ranging in molecular mass from 10 to $220 \mathrm{kDa}$, was used.

\subsection{Statistical Analysis}

This was performed by comparing the means through analysis of variance (ANOVA) using Statistic 7.0 (Statsoft $^{\mathrm{TM}}$, Inc., Tulsa, OK, USA).

\section{Results and Discussion}

\subsection{Proximate Composition}

Table 1 shows the proximate composition (\%) of protein recovered from Whitemouth Croaker byproducts (PRWC).

As shown in Table 1 protein content was found to be superior, and the moisture was within the range found by Centenaro and Mellado [21] that found in croaker hydrolyzed protein values ranging from $49.7 \%$ to $80.3 \%$ and moisture of $7.2 \%$ to $13.1 \%$.

Regarding the content of ash and lipid values in Table 1 were similar to those found in fish surimi by CortezVega et al. [22] that were $2.9 \%$ and $1.7 \%$ for ash and lipids respectively.

Table 1. Proximate composition (\%) of protein recovered from Whitemouth Croaker byproducts (PRWC).

\begin{tabular}{cc}
\hline Compound & PRWC (\% d.b. $)^{*}$ \\
\hline Moisture & $8.64 \pm 0.10$ \\
Protein & $85.33 \pm 0.12$ \\
Ashes & $2.69 \pm 0.09$ \\
Lipids & $2.16 \pm 0.12$ \\
\hline
\end{tabular}

${ }^{*}$ Results are mean \pm standard deviation of triplicate analyses, d.b.: dry basis.
Martins et al. [23] found in isolates of croaker protein obtained by acid extraction the following amounts to $86.94 \%$ protein, $3.47 \%$ fat and less than $1.0 \%$ ash. These values are similar to those found in this study, with a greater variation in ash content.

\subsection{Solubility}

The highest solubility was obtained at $\mathrm{pH}$ extremes, as in Figure 1, was obtained at $\mathrm{pH} 11$ higher values (93.24\%). The high solubility of protein isolates indicates potential applications in formulated food by providing an attractive appearance and a smooth mouthfeel to the product prepared [24].

The results agree with Freitas [25] that found in isolated muscle from croaker solubility value of $58.06 \%$ and $98.06 \%$ for $\mathrm{pH} 3.0$ and $\mathrm{pH} 11.0$, respectively. Both Rawdkuen et al. [26] as Batista et al. [27] with higher solubility surimi obtained when using three washing cycles when it was compared with the protein isolated by the process of varying $\mathrm{pH}$. The same can be observed in this study to compare the recovered protein from byproducts croaker.

Rawdkuen et al. [26], in assessing muscle protein solubility for tilapia $\mathrm{pH} 7$ was obtained in $0.57 \mathrm{mg} / \mathrm{g}$ for the protein obtained by the alkaline solubilization and $0.23 \mathrm{mg} / \mathrm{g}$ for the protein obtained by the acid process, these authors have argued that the low solubility of the protein is probably caused by denaturation of the muscle protein induced by $\mathrm{pH}$ change process, which was not observed in this study because the recovery and concentration of proteins was performed by washing process.

\subsection{Water Holding Capacity (WHC)}

It is known that the capacity for water retention is an important phenomenon in foods, because water absorbed in small amounts does not act as a solvent but contributes to give body and increase viscosity, Cândido et al. [28].

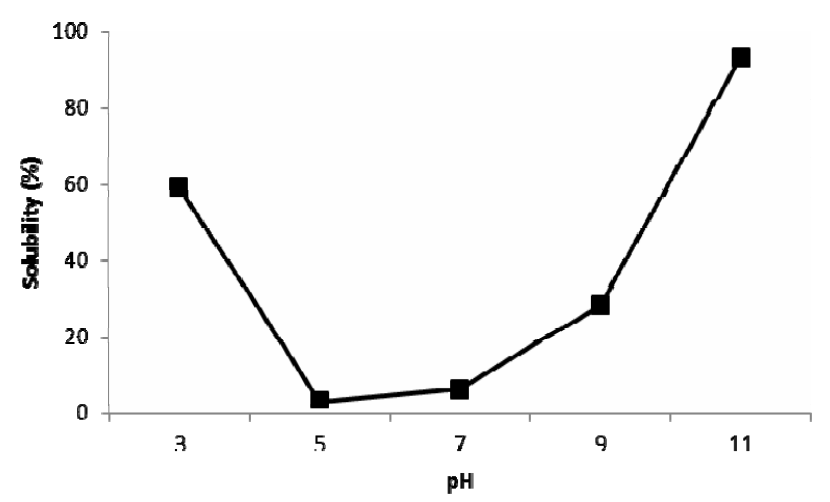

Figure 1. Solubility curve of protein for protein recovered from Whitemouth Croaker byproducts. 
Figure 2 shows the WHC at different pHs. It is observed that the WHC increased with increasing $\mathrm{pH}$, the higher value of WHC was at $\mathrm{pH} 11.0$ (25.71 mL water/g protein).

There was a reduction in $\mathrm{WHC}$ at $\mathrm{pH} 5.0$, then, near the isoelectric point of the protein occurs a decrease in the ability of the protein to bind with the water, due to intermolecular interactions, Kelleher and Hultin [29]. At $\mathrm{pH}$ below 5.0 and above 7.0, the water molecules are combined with the polar groups of the proteins occurs and increasing the WHC.

Fontana et al. [30] obtained at $\mathrm{pH} 11.0$, the maximum values of 21.9 and $22.9 \mathrm{~mL}$ water/protein in isolates from croaker process by acid and alkaline solubilization, respectively, agreeing with the results obtained in this study.

\subsection{Oil Holding Capacity (OHC) and Digestibility in Vitro}

Table 2 show the values found of oil holding capacity and the digestibility in vitro of protein recovered from Whitemouth Croaker byproducts (PRWC).

The $\mathrm{OHC}$ is an important attribute, as it influences the taste of food, it is a functional feature required mainly in the meat and emulsions industry.

Table 2 shows that the holding capacity of the oil PRWC, this study was greater than that found by other authors. Lin and Zayas [31] showed that high oil holding capacity of fish protein can be when it has a low content of lipids.

Freitas et al. [32] found $7.27 \mathrm{~mL}$ oil/g protein for the protein isolate of Argentine anchovy (Engraulis anchoita) wastes obtained by the process alkaline solubilization.

Sathivel and Bechtel [33] in isolated proteins of byproducts Alaska pollock (Theragra chalcogramma), obtained $3.5 \mathrm{ml}$ of $\mathrm{oil} / \mathrm{g}$ of protein.

It is known that heat is responsible for the increased

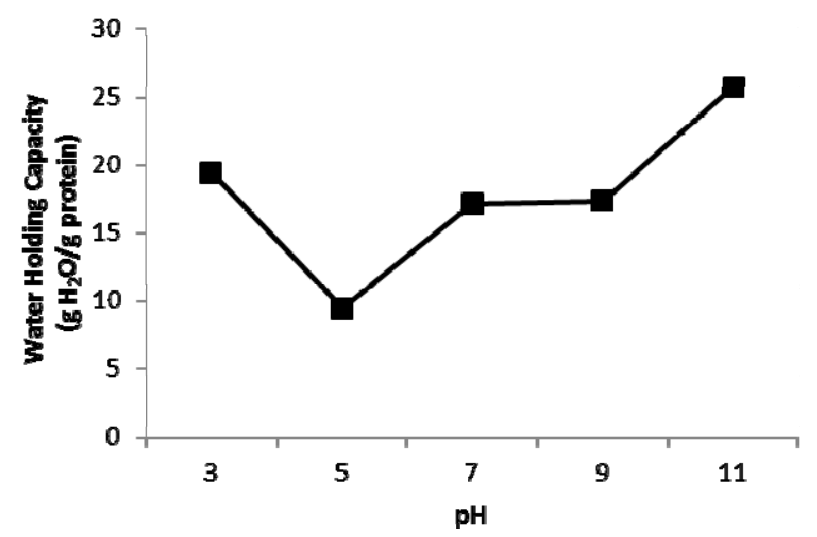

Figure 2. Water holding capacity (WHC) of protein for protein recovered from Whitemouth Croaker byproducts. digestibility due to inactivation of some antinutritional factors such as protease inhibitors. The protease inhibitors are substances of protein nature, present naturally in some foods that affect the activity of enzyme systems of the digestive tract, especially by inhibiting proteases, which are enzymes that hydrolyze the peptide bonds as a first step towards the assimilation of proteins, Castro et al. [34].

In relation to digestibility in isolated proteic shrimp, Costa et al. [35] found values of $99.2 \%$, higher than found in this study as shown in Table 2.

\subsection{Electrophoresis of Protein Recovered}

Through Figure 3 shows that the two samples (2 and 3) of the protein recovered showed a similar electrophoretic profile.

On proteins recovered from Whitemouth Croaker (Micropogonias furnieri) byproducts observed electrophoretic profiles typical of the myofibrillar proteins, with the appearance of the heavy chain of myosin $(220 \mathrm{kDa})$ and actin $(50 \mathrm{kDa})$. Were identified also other fractions with molecular weight between 20 and $50 \mathrm{kDa}$, such as troponins I, C and T; myosin light chains as well as $\alpha$ and $\beta$ tropomyosin.

In protein of Nile Tilapia (Oreochromis niloticus), Tongnuanchan et al. [36] also found heavy chain myosin, actin and troponin proteins as dominant, well as Monterrey-Quintero and Sobral [37], who analyzed the electrophoretic profile of Nile Tilapia (Oreochromis niloticus)

Table 2. Values found in the analysis of oil holding capacity and the digestibility in vitro, for PRWC.

\begin{tabular}{ccc}
\hline Sample & $\begin{array}{c}\text { Oil holding capacity } \\
(\mathrm{mL} \text { oil } / \mathrm{g} \text { protein })^{*}\end{array}$ & Digestibility in vitro $(\%)^{*}$ \\
\hline PRWC & $13.17 \pm 0.11$ & $91.32 \pm 0.15$ \\
\hline${ }^{*}$ Results are mean \pm standard deviation of triplicate analyses, $\mathrm{d} \cdot \mathrm{b} \cdot \mathrm{d}$ dry basis.
\end{tabular}

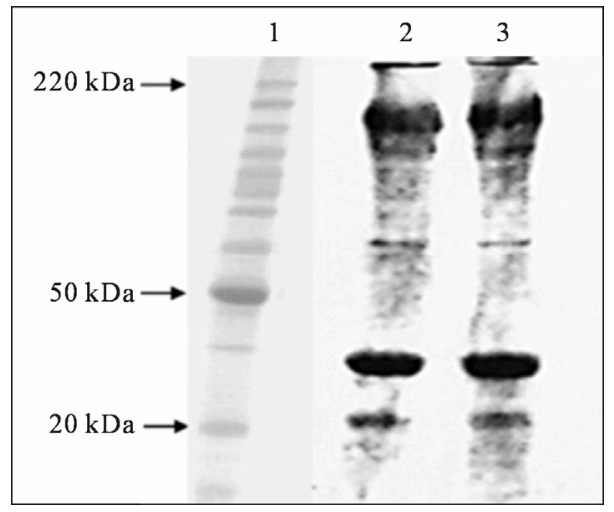

Figure 3. Electrophoretic profile of proteins present in the pattern (1) and the protein recovered byproduct croaker ( 2 and 3) obtained by SDS-PAGE. 
and found similar results to the present work. Moreover, Cuq et al. (1995) [38] studied the myofibrillar proteins of sardine (Sardine pilchardus) identified similar bands, but these authors did not separate troponin and tropomyosin into its subunits. In the electrophoretic profiles were also identified minor bands with molecular masses of $20 \mathrm{kDa}$. These fractions smaller masses present in the protein recovered possibly are due to the process of obtaining by the method of alkaline solubilization, in which parts of the proteins to hydrolyze proteins of lower molecular weight, and therefore appear bands with molecular weight lower.

\section{Conclusions}

The protein recovered obtaining from Whitemouth Croaker (Micropogonias furnieri) byproducts, showed a higher solubility and water retention capacity at $\mathrm{pH}$ extremes. This protein exhibited high oil retention capacity and high digestibility in vitro, and the electrophoretic profile was typical of the myofibrillar proteins, with the appearance of the heavy chain of myosin and actin.

The results show that the products of low commercial value of fish that are usually used for the production of animal feed or simply discarded, contributing to environmental pollution, may be used to produce products with a greater added value.

\section{Acknowledgements}

The authors are grateful with Brazilian Agencies CAPES and $\mathrm{CNPq}$, for the financial support to this research.

\section{REFERENCES}

[1] A. A. Gonçalves and M. G. Passos, "Restructured Fish Product from White Croacker (Micropogonias furnieri) Mince Using Microbial Transglutaminase," Brazilian Archives of Biology and Technology, Vol. 53, No. 4, 2010, pp. 987-995. doi:10.1590/S1516-89132010000400030

[2] H. Nolsoe and I. Undeland, "The Acid and Alkaline Solubilization Process for the Isolation of Muscle Proteins: State of the Art," Food Bioprocess and Technology, Vol. 2, No. 1, 2009, pp. 1-27. doi:10.1007/s11947-008-0088-4

[3] I. R. Freitas, G. V. Gautério, D. G. Rios and C. Prentice, "Functionality of Protein Isolates from Argentine Anchovy (Engraulis anchoita) Residue Obtained Using pH Shift Processing," Journal of Food Science and Engineering, Vol. 1, No. 5, 2011, pp. 374-378.

[4] A. K. Rai, H. C. Swapna, N. Bhaskar, P. M. Halami and N. M. Sachindra, "Effect of Fermentation Ensilaging on Recovery of Oil from Fresh Water Fish Viscera," Enzyme and Microbial Technology, Vol. 46, No. 1, 2010, pp. 9-13. doi: 10.1016/2fj.enzmictec.2009.09.007

[5] E. S. G. Contreras, "Bioquímica de Pescados e Derivados," FUNEP, Jaboticabal, 1994, pp. 315-330.
[6] Y. C. Chen and J. Jaczynski, "Protein Recovery from Rainbow Trout (Oncorhynchus mykiss) Processing Byproducts via Isoelectric Solubilization/Precipitation and Its Gelation Properties as Affected by Functional Additives," Journal of Agricultural and Food Chemistry, Vol. 55, No. 22, 2007, pp. 9079-9088. doi:10.1021/jf071992w

[7] L. Taskaya and J. Jaczynski, "Flocculation-Enhanced Protein Recovery from Fish Processing Byproducts by Isoeletric Solubilization/Precipitation," Food Science and Technology, Vol. 42, No. 2, 2009, pp. 570-575.

[8] V. G. Martins, J. A. V. Costa, S. T. Silveira, A. Brandelli and C. H. Prentice, "Protein and Amino Acid Solubilization by Using Bacillus cereus, Bacillus velesensis, and Chryseobacterium sp. from Chemical," Food and Bioprocess Tecnhology, Vol. 4, No. 1, 2011, pp. 116-123.

[9] Y. Thiansilakul, S. Benjakul and F. Shahidi, "Compositions, Functional Properties and Antioxidative Activity of Protein Hydrolysates Prepared from round Scad (Decapterus maruadsi)," Food Chemistry, Vol. 103, No. 4, 2007, pp. 1385-1394. doi:10.1016/j.foodchem.2006.10.055

[10] S. G. Chaud and V. C. Sgarbieri, "Propriedades Funcionais (Tecnológicas) da Parede Celular de Leveduras da Fermentação Alcoólica e das Frações Glicana, Manana e Glicoproteína," Ciência e Tecnologia de Alimentos, Vol. 26, No. 2, 2006, pp. 369-379. doi:10.1590/S0101-20612006000200020

[11] W. R. Cortez-Vega, G. G. Fonseca, V. A. Feisthera, T. F. Silva and C. Prentice, "Evaluation of Frankfurters Obtained from Croaker (Micropogonias furnieri) Surimi and Mechanically Deboned Chicken Meat Surimi-Like Material," Journal of Food, Vol. 11, No. 1, 2013, pp. 27-36. doi:10.1080/19476337.2012.680199

[12] A.O.A.C, "Association of Official Analysis Chemists," 16th Edition, Washington DC, 1995.

[13] M. Chalamaiah, G. N. Rao, D. G. Rao and T. Jyothirmayi, "Protein Hydrolysates from Meriga (Cirrhinus mrigala) Egg and Evaluation of Their Functional Properties," Food Chemistry, Vol. 120, No. 3, 2010, pp. 652-657. doi:10.1016/j.foodchem.2009.10.057

[14] P. Tadpitchayangkoon, J. W. Park and J. Yongsawatdigul, "Conformational Changes and Dynamic Rheological Properties of Fish Sarcoplasmic Proteins Treated at Various pHs," Food Chemistry, Vol. 121, No. 4, 2010, pp. 10461052. doi:10.1016/j.foodchem.2010.01.046

[15] O. H. Lowry, N. J. Rosebrough, A. L. Farr and R. J. Randall, "Protein Measurement with the Folin Phenol Reagent," Journal of Biological Chemistry, Vol. 193, No. 1, 1951, pp. 265-275.

[16] J. M. Regenstein, C. A. Jauregui and R. Baker, "The Effect of $\mathrm{pH}$, Polyphosphates and Different Salt on Water Retention Properties of Ground Trout Muscle," Journal of Food Biochemistry, Vol. 8, No. 2, 1984, pp. 123-131. doi:10.1111/j.1745-4514.1984.tb00320.x

[17] M. M. Bradford, "A Rapid and Sensitive Method for the Quantitation of Microgram Quantities of Protein Utilizing the Principle of Protein-Dye Binding," Analytical Biochemistry, Vol. 72, No. 1-2, 1976, pp. 248-254. doi:10.1016/0003-2697(76)90527-3 
[18] L. G. Fonkwe and R. K. Singh, "Protein Recovery from Mechanically Deboned Turkey Residue by Enzymic Hydrolysis," Process Biochemistry, Vol. 31, No. 6, 1996, pp. 605-616. doi:10.1016/S0032-9592(95)00101-8

[19] V. Feddern, S. S. Pinto, K. A. Nogueira, E. B. Furlong and L. A. S. Soares, "Influência da Composição e da Fermentação nas Propriedades Fisico-Quimicas e Nutricionais de Multimisturas," Brazilian Journal of Food Technology, Vol. 11, No. 2, 2008, pp. 128-133.

[20] U. K. Laemmli, "Cleavage of Structural Proteins during the Assembly of the Head of Bacteriophage T4," Nature, Vol. 227, No. 1, 1970, pp. 680-685.

doi: $10.1038 / 227680 \mathrm{a} 0$

[21] G. S. Centenaro and M. S. Mellado, "Influência das Concentrações de Enzima e de Substrato no Grau de Hidrólise e no Conteúdo Protéico de Hidrolisados Enzimáticos de Corvina (Micropogonias furnieri)," B. CEPPA, Vol. 26, No. 1, 2008, pp. 61-70.

[22] W. R. Cortez-Vega, G. G. Fonseca, V. A. Feisther, T. F. Silva and C. Prentice, "Evaluation of Frankfurters Obtained from Croaker (Micropogonias furnieri) Surimi and Mechanically Deboned Chicken Meat Surimi-Like Material," CyTA-Journal of Food, Vol. 10, No. 1, 2012, pp. 190-199.

[23] V. G. Martins, J. A. V. Costa and C. Prentice, "Hidrolisado Proteíco de Pescado Obtido por vias Química e Enzimática a Partir de Corvina (Micropogonias funieri)," Química Nova, Vol. 32, No. 1, 2009, pp. 61-66. doi:10.1590/S0100-40422009000100012

[24] S. Sathivel, P. Bechtel, W. P. Babbitt, I. I. Nesgulescu and K. Reppond, "Properties of Protein Powders from Arrowtooth Flounder (Atheresthes stomias) and Herring (Clupeaharengus) Byproducts," Journal of Agricultural and Food Chemistry, Vol. 52, No. 16, 2004, pp. 50405046. doi:10.1021/jf0351422

[25] I. R, Freitas, "Otimização do Processo de Obtenção de Isolados Proteicos Provenientes de Pescado de Baixo Valor Comercial," Dissertation, University of Rio Grande, Rio Grande, 2011.

[26] S. Rawdkuen, S. Sai-ut, S. Khamsorn, M. Chaijan and S. Benjakul, "Biochemical and Gelling Properties of Tilapia Surimi and Protein Recovered Using Acid-Alkaline Process," Food Chemistry, Vol. 112, No. 1, 2009, pp. 112119. doi:10.1016/j.foodchem.2008.05.047

[27] I. Batista, C. Pires and R. Nelhas, "Extraction of Sardine Proteins by Acidic and Alkaline Solubilisation," Food Science and Technology International, Vol. 13, No. 3, 2007, pp. 189-194. doi:10.1177/1082013207079619

[28] L. M. B. Cândido, A. K. Nogueira and V. C. Sgarbieri, "Propriedades Funcionais de Concentrados Proteicos de Pescado Preparados por Vários Métodos," Brazilian Journal of Food Technology, Vol. 1, No. 1-2, 1998, pp. 77-89.
[29] H. O. Hultin and S. D. Kelleher, "Process for Isolating a Protein Composition from a Muscle Source and Protein Composition," Advanced Protein Technologies Inc., Rockport, 1999.

[30] A. Fontana, G. S. Centenaro, S. C. Palezi and C. PrenticeHernández," Obtenção e Avaliação de Concentrados Proteicos de Corvina (Micropogonias furnieri) Processados por Extração Química," Química Nova, Vol. 32, No. 9, 2009, pp. 2203-2299. doi:10.1590/S0100-40422009000900011

[31] C. S. Lin and J. F. Zayas, "Functionality of Defatted Corn Germ Proteins in a Model System: Fat Binding Capacity and Water Retention," Journal of Food Science, Vol. 52, No. 5, 1987, pp. 1308-1311. doi:10.1111/j.1365-2621.1987.tb14070.x

[32] I. R. Freitas, G. V. Gautério, D. G. Rios and C. Prentice, "Functionality of Protein Isolates from Argentine Anchovy (Engraulis anchoita) Residue Obtained Using $\mathrm{pH}$ Shift Processing," Journal of Food Science and Engineering, Vol. 1, No. 5, 2011, pp. 374-378.

[33] S. Sathivel and P. Bechtel, "Properties of Soluble Protein Powders from Alaska Pollock (Theragra chalcogramma)," International Journal of Food Science and Technology, Vol. 41, No. 5, 2006, pp. 520-529. doi:10.1111/j.1365-2621.2005.01101.x

[34] L. I. A. Castro, C. M. Vila Real and C. I. S. Pires, "Quinoa (Chenopodium quinoa willd): Digestibilidade in Vitro, Desenvolvimento e Análise Sensorial de Preparações Destinadas a Pacientes Celíacos," Alimentos e Nutrição, Vol. 18, No. 4, 2007, pp. 413-419.

[35] P. G. Costa, A. Fontana, I. Veiga and C. Prentice, "Caracterização Funcional e Nutricional de um Isolado Protéico Obtido a Partir de Resíduos de Camarão Rosa (Farfantepenaeus paulensis)," Alimentação e Nutrição, Vol. 18, No. 1, 2007, pp. 7-18.

[36] P. Tongnuanchan, S. Benjakul and T. Prodpran, "Roles of Lipid Oxidation and $\mathrm{pH}$ on Properties and Yellow Discolouration during Storage of film from Red Tilapia (Oreochromis niloticus) Muscle Protein," Food Hydrocolloids, Vol. 25, No. 3, 2011, pp. 426-433. doi:10.1016/j.foodhyd.2010.07.013

[37] E. S. Monterrey-Quintero and P. J. A. Sobral, "Preparo e Caracterização de Proteínas Miofibrilares de Tilápia-doNilo Para Elaboração de Biofilmes," Pesquisa Agropecuária Brasileira, Vol. 35, No. 1, 2000, pp. 179-189. doi:10.1590/S0100-204X2000000100020

[38] B. Cuq, N. Gontard, J. Cuq and S. Guilbert, "Functional Properties of Myofibrilar Protein-Based Biopackaging as Affected by Film Thickness," Journal of Food Science, Vol. 61, No. 3, 1996, pp. 580-584. doi:10.1111/j.1365-2621.1996.tb13163.x 